\title{
Leszek Karczewski
}

Uniwersytet Łódzki

Instytut Kultury Współczesnej

\section{Komiksiara z suchymi oczami Fun Home Alison Bechdel jako krypto-bio-grafia}

Fun Home to komiksowa Künstlerroman Alison Bechdel ${ }^{1}$.

Tytułowy Fun Home to zakład pogrzebowy (oraz ironiczny skrót od Funeral Home). W głównym wątku narracji autorka wielokrotnie powraca do śmierci ojca, Bruce'a Bechdela, nauczyciela angielskiego w college'u, lokalnego przedsiębiorcy pogrzebowego i kryptogeja, śmierci pod kołami ciężarówki, śmierci, która mogła być samobójstwem; wątek ten jest prze-pisywany poprzez gąszcz aluzji do kanonu literackiego, mitów i kultury popularnej. Wypadek ten zbiega się w czasie z coming outem Alison jako samoświadomej lesbijki.

Alison Bechdel czyni wiele, by Fun Home sprawiał wrażenie dokumentarne - już to zamieszczając w książce przerysowane fotografie z rodzinnego archiwum, drobiazgowym szrafowaniem zbliżone do dziewiętnastowiecznych rycin, już to skrupulatnie odwzorowując detale architektoniczne rodzinnego domu i wystroju poszczególnych pokojów w kolejnych kadrach; oddaje deski szczytowe, biedermeierowskie meble i secesyjne szkło artystyczne z nieprzepartą mimetyczna mocą. Ma to swoje uzasadnienie fabularne: pasją Bruce'a Bechdela jest renowacja zabytków, pasją, jak pisze Bechdel, „w każdym znaczeniu tego słowa. Libidalnym. Maniakalnym. Męczeńskim” $(15)^{2}$. Bruce, jako „Dedal wystroju” (14), a może raczej Midas, zmienia dom w „symulakrum domu, muzeum” (25). Ornament „wolut, frędzli i ozdóbek” (24) przedostaje się

${ }^{1}$ Tę trafną atrybucję formułuje między innymi D.M. Ball, Allusive Confessions. The Literary Lives of Alison Bechdel's Fun Home, [w:] Drawing from Life. Memory and Subjectivity in Comic Art, ed. J. Tolmie, Jackson 2013, s. 3.

${ }^{2}$ Cytaty z Fun Home lokalizuję w tekście głównym w nawiasach, za wydaniem: A. Bechdel, Fun Home. Tragikomiks rodzinny, przeł. W. Szot, S. Buła, Warszawa 2010. Komiks cytuję, zamieniając charakterystyczne dla komiksu wersaliki na standardową formę zapisu tekstu. 
z realnego świata do kadrów Fun Hume, pełniąc przy tym analogiczną funkcję. Ostentacyjny estetyzm maskujący sekret Bruce’a uwodzącego nastoletnich chłopców - ale przecież będący jego równie ostentacyjnie stereotypową ekspresją - zmienia się w złożoną ikoniczno-werbalną maskę narracyjnych strategii ujawniania i ukrywania, obranych przez Bechdel. Wielu badaczom jednak wydaje się wystarczać genologiczna atrybucja Fun Home jako autografii, w której obecność autorskiego podmiotu zostaje niejako dokumentacyjnie poświadczona przez komiksową grafikę traktowaną jako autograf ${ }^{3}$. Ujmowanie powieści Bechdel w kategoriach archiwum ${ }^{4}$ nie okazuje się płodne poznawczo: efektem bywają co najwyżej eseistyczne banały o kontrapunktowaniu autografii i autobiografii w „nieprzerwanej spirali odbić”. Bechdel, jak teoretyczka literatury, wielokroć uprzytamnia czytelnikowi dystansującą pozycję pamiętnikarza: zawodność pamięci, przepaść oddzielającą mówiącego w tekście od autora oraz różnorodne sposoby, na jakie kształtowane są wspomnienia i konstruowane opowieści, co komplikuje kategoryczność twierdzeń o autobiografizmie.

Bechdel-autorka konstruuje w Fun Home zarówno siebie-jako-narratorkę, jak i siebie-jako-postać, Alison, będącą przedmiotem owej narracji, dodatkowo ikonicznie auto-portretując się w obu rolach. Poziomy ekstradiegetyczny (dalej konsekwetnie: Bechdel) i intradiegetyczny (Alison) zostają uzupełnione poziomem obrazu, który w charakterystyczny dla autografii sposób tworzy efekt nieosiągalny w prozatorskiej autobiografii ${ }^{6}$. Bywa, że dla porządku empiryczna Bechdel bywa nazywana akronimem T-RAB: The Real Alison Bechdel7.

Ten złożony obraz memuarystki Bechdel buduje poprzez równie złożone zabiegi. Po pierwsze: prze-pisuje prywatną historię rodziny sprzed własnych urodzin, włączając w narrację sceny ze służby wojskowej ojca w Republice Federalnej Niemiec czy z miesiąca miodowego rodziców, który spędzili w Paryżu, by Bruce mógł odwiedzić dawnego kochanka, rysując je „z wyobraźni” (choć zapewne na podstawie rodzinnych archiwów). Wraz

${ }^{3}$ Zob. R. Warhol, The Space Between: A Narrative Approach to Alison Bechdel's „Fun Home”, „College Literature” 2011, vol. 38, no. 3, s. 1-20.

${ }^{4}$ A. Cvetkovich, Drawing the Archive in Alison Bechdel's “Fun Home”, „Women's Studies Quarterly” 2008, vol. 36, no. 1-2, s. 111-128.

${ }^{5}$ J. Watson, Autographic Disclosures and Genealogies of Desire in Alison Bechdel's "Fun Home”, „Biography” 2008, vol. 31, no. 1, s. 27-58.

${ }^{6}$ Robyn Warhol (tejże, The Space Between..., s. 1-20) dowodzi, że jest to głębia psychologiczna.

7 Tak jest na przykład w clipie Alison Bechdel's Fun Home on Broadway z kanału StuckinVermont - zob. https://www.youtube.com/watch?v=A9vD7NcoL3k [dostęp 11.05.2015]. 
z traumą niemożliwego coming outu Bruce'a, powtórzoną poprzez coming out własny, Bechdel wpisuje swoją narrację w nurt postpamięci ${ }^{8}$, co jest chętnie podejmowane przez komentatorów, stawiających Fun Home w jednym rzędzie z Maus Arta Spiegelmana (1993) oraz Persepolis Marjane Satrapi (2003) ${ }^{9}$. Traumę prywatną Bechdel wpisuje w kontekst publicznej traumy przywoływanych historycznych wydarzeń, jakimi były zamieszki Stonewall (1969) czy afera Watergate $(1972-1974)^{10}$.

Po drugie: Bechdel ujawnia własny epistemologiczny kryzys jako młodej pamiętnikarki: „Skąd miałam mieć pewność, że wydarzenia, które opisywałam, działy się naprawdę?" (149); kategoryczność twierdzeń uchyla dopisek „chyba”, ustępujący miejsca symbolowi cyrkumfleks, który użycza magii wątpienia wszelkim imionom i zaimkom, a z czasem zamazuje całe strony.

Po trzecie i najważniejsze: Bechdel ustanawia narracyjny dystans czy kontrapunkt między werbalną a ikoniczną zawartością plansz. Reprezentatywna jest tu „archiwalna” rozkładówka komiksu (108-109); za centralne miejsce powieści uznają ją niemal wszyscy interpretatorzy. Rozkładówka przedstawia Roya, chłopaka do pomocy w domu Bechdelów, opiekuna Alison i kochanka jej ojca. Widzimy go na archiwalnej fotografii z 1969 roku, znalezionej w kopercie, „którą ojciec podpisał «rodzina»”. Odkrywszy ją, Bechdel przeżyła olśnienie, które doprowadziło do wygenerowania całej powieści graficznej. W rozmowie z Hillary Chute autorka wspomina:

To było olśnienie, wgląd w równoległą egzystencję. To było absolutnie nie do przecenienia, byłam dopiero co po coming oucie. I poczułam więź ze zmarłym ojcem jak z kumplem. Choć nie rozpoczęłam pracy nad komiksem, to przez lata owa fotografia istniała w mojej pamięci. To dosłownie rdzeń książki ${ }^{11}$.

Rdzeń książki i tym samym centrum labiryntu. Podobizna Roya to jedyna taka plansza w komiksie Bechdel. W żadnym innym miejscu kadr nie zajmuje całej planszy - w tym wypadku nawet dwóch plansz. Żadna inna plansza nie wymaga druku „na spad”; na pozostałych stronach kadry komiksu otoczone są wyraźnymi ramkami. Nadto, plansza z Royem została ukryta w środku tekstu.

${ }^{8}$ Pojęcie Marianne Hirsch, zob. tejże, Pokolenie postpamięci, przeł. M. Borowski, M. Sugiera, „Didaskalia” 2011, nr 105, s. 28-36.

${ }^{9}$ Zob. między innymi A. Cvetkovich, Drawing the Archive..., s. 111-128; J. Lemberg, Closing the Gap in Alison Bechdel's “Fun Home”, „Women's Studies Quarterly” 2008, vol. 36, no. 1-2, s. 129-140.

${ }^{10} \mathrm{~J}$. Gardner, Projections: Comics and the History of Twenty-First-Century Storytelling, Stanford (CA) 2012, s. 142.

${ }^{11}$ Zob. H. Chute, An Interview with Alison Bechdel, „Modern Fiction Studies” 2006, vol. 52, no. 4, s. 1005-1006. 
Zdjęcie - komentuje Alison - „Zostało zrobione w wakacje, kiedy Roy towarzyszył ojcu, moim braciom i mnie w podróży na wybrzeże Jersey. Miałam osiem lat. Mama odwiedzała w tym czasie swoją dawną współlokatorkę w Nowym Jorku. [...] Pamiętam ten pokój hotelowy. Spałam z braćmi w sąsiednim" (108). Narracja Alison zmienia fotografię Roya w figurę ujawnienia i ukrycia, charakteryzującą wspomnienia. Afektywny i konfesyjny autorytet fotografii, mimetyczna moc książki Bechdel i centralna rola w porządku tekstualnym sprawiają, że łatwo zapomnieć, iż ten obraz nie oddaje przeżytego doświadczenia. Że Roy w samych szortach „skąpany w porannym słońcu" (108) - to nie jest Roy.

To nie jest Roy z powodów pryncypialnych: wszak Bechdel nie umieszcza w książce fotografii Roya, lecz przedstawiający ją rysunek, który jako taki nie denotuje, lecz konotuje jedynie, stąd nie zaświadcza o rzeczywistości. Warto jednak przypomnieć, że nie istnieją wszak techniczne przeszkody, dla których nie można by było zreprodukować w książce prawdziwej fotografii ${ }^{12}$.

To nie jest Roy także z tak trywialnych powodów prawnych, jak ochrona danych osobowych bohaterów memuarystycznej opowieści. Zarówno „Roy”, jak i jego wygląd są odpowiednio pseudonimem i awatarem. Jak twierdzi David M. Ball, ani imię Roya, ani jego cielesna reprezentacja z Fun Home nie odpowiadają danym z prywatnego archiwum prawdziwego Bruce'a Bechdela ${ }^{13}$.

Nadto, kompozycja narysowanej fotografii Roya, a także jej opis („Słaba ostrość nadaje zdjęciu eterycznej, malarskiej jakości. Roy jest skąpany w porannym słońcu. Jego włosy wyglądają jak aureola”, 108) podsuwają trop aktu jako tematu sztuki. Bechdel rozrzuca poszlaki w tekście wielokrotnie. Portretuje Bruce’a czytającego (oglądającego?) książkę Kenetha Clarka Akt. Studium idealnej formy z torsem Dawida dłuta Michała Anioła na okładce $(23,107)$. Na planszy bezpośrednio poprzedzającej rozkładówkę z Royem zarówno Bruce, jak i Alison podziwiają męski półakt z reklamy w „Esquire”.

Plansza z Royem odsłania więcej niż reklama, w której spodnie garnituru skromnie osłaniają w pasie przedmiot pożądania. Jednak i w wypadku Roya cień, spowijający model na przerysowanej fotografii, oraz - jak dowodzi Ball - szycie stron książki nieprzypadkowo zaplanowane w newralgicznym miejscu, w pasie Roya, nie spełniają ewentualnych voyerystycznych marzeń czytelników. Rozkładówka z Royem ujawnia zatem romans Bruce’a, jednocześnie ukrywając imię i wygląd jego kochanka; pochodzi z rodzinnych archiwów, ale

${ }^{12}$ Przytomnie zauważa to Helene Tison: tejże, Loss, Revision, Translation: Re-Membering the Father's Fragmented Self in Alison Bechdel's Graphic Memoir Fun Home: A Family Tragicomic, „Studies in the Novel” 2015, vol. 47, no. 3, s. 346-364.

${ }^{13}$ D.M. Ball, Allusive Confessions..., s. 7. 
zostaje prze-pisana przez historię artystycznych praktyk i archetypicznych ujęć; podsuwa dowód cielesnych pasji Bruce'a, ale samo ciało ukrywa ${ }^{14}$.

Zatem wbrew pozorom Bechdel cenzoruje informacje, a plansza z Royem stanowi metonimię cenzorskiej dialektyki ujawniania i ukrycia Fun Home. Jeśli autorka ujawnia archiwalne dokumenty rodzinne, to zmienione - powtarzając tym samym gesty własnego ojca, komentowane przez Alison jako „kuriozalnie wręcz nieefektywna próba cenzury” (109). Alison gorzko ocenia Bruce’a: „w tym akcie prestidigitatorstwa, typowym dla ojca żonglowaniu swoim wizerunkiem publicznym i życiem prywatnym, wszelkie dowody są niejasne i jednocześnie oczywiste” (109). Bechdel włącza się w tę samą dialektykę ujawniania i ukrycia, jako odzwierciedlenie praktyk Bruce'a, przez reprezentację Roya, ale i Bruce'a, a nawet siebie samej jako Alison, w całym tekście.

Przerysowana fotografia Roya jest zaprezentowana jako trzymana między kciukiem a palcem wskazującym lewej dłoni, także narysowanej, należącej do Alison. To równie symboliczne ukazanie procederu ujawniania i ukrycia. Druk na spad w komiksie nie tylko powiększa kadr, ale też zaciera granicę między światem narysowanym a rzeczywistością ${ }^{15}$. W wypadku planszy z Royem dłoń Alison staje się ręką Bechdel (której, zapewne, jako praworęcznej łatwiej było odrysować własną lewą rękę trzymającą fotografię). Jej kontur, urwany przez otwartą kompozycję, pokrywa się z realnym konturem dłoni potencjalnych czytelników, trzymających komiks. W ten sposób Bechdel komplikuje poziomy mediacji separujących Alison i zewnątrztekstowych odbiorców od reprezentowanych wydarzeń.

Rozkładówka z Royem ucieleśnia oscylację ujawniania i ukrycia - ale w Fun Home napotyka się ją na każdym kroku. Szerszy kontekst dla niej stanowi problem cenzury i autocenzury we współczesnej gejowskiej i lesbijskiej kulturze wizualnej, w której Fun Home przecież prześwietnie partycypuje. Richard Meyer w pracy Outlaw Representation: Censorship and Homosexuality in Twentieth-Century American Art dowodzi, że " "negatywne» obrazy homoseksualności - obraz przestępstwa i grzechu, choroby czy stereotypu - stanowią istotną część pikturalnego języka” jako swoista „regulacja homoseksualności”. Jednakże ta normatywizacja „sprowokowała niespodziane reakcje i przeciwreprezentacje, niewidzialne obrazy różnicy i świadome siebie inscenizacje dewiacji” ${ }^{16}$. Ten sam represyjny reżim

${ }^{14}$ Zob. tamże.

${ }^{15}$ Zob. S. McCloud, Making Comics. Storytelling Secrets of Comics, Manga and Graphic Novels, New York 2006, s. 163-164.

${ }^{16}$ R. Meyer, Outlaw Representation. Censorship and Homosexuality in Twentieth-Century American Art, Boston 2004, s. 8-10. Mayera przywołuje: D.M. Ball, Allusive Confessions..., s. 8. 
wymuszający niewidzialność gejów i obowiązkowy heteroseksualizm, według Meyera, daje artystom narzędzia do naruszania tych struktur czynienia widzialnym i samo-obrazowania. Cenzurę stanowi tu urządzenie generatywne dla artystów queer, które:

Zmusza twórcę do niebezpośredniości i „pomysłowego przebrania”. Cenzura produkuje a zarazem zakazuje pisania; nakazuje pisarzowi nie tyle milczeć, ile strategicznie używać sugestii i metafor, podtekstów i zakodowanych znaczeń [...]. W dialektycznej koncepcji cenzura nie działa po prostu, by wymazać, ale również, by umożliwić reprezentację; tworzy granice, ale także reakcje na nie; nakłada milczenie, ale prowokuje reakcje na tę ciszę ${ }^{17}$.

W interpretacji Meyera, paradoksalnie, to właśnie represja umożliwia gejowską i lesbijską ekspresję wizualną; dialektyka cenzury i autocenzury wydaje się istotniejsza w wypadku lesbijskich artystek, które niemal do końca XX wieku były niewidoczne w kulturze amerykańskiej ${ }^{18}$.

Dla Bechdel relacja ta, z pozoru, wydaje się nieistotna. Autorka jest niezwykle otwarta. Po pierwsze, od 1987 roku publikuje plansze lesbijskiego komiksu Dykes to Watch Our For (ponad pięćset), w których występuje pod imieniem bliźniaczego do Alison awatara - $\mathrm{Mo}^{19}$. Na planszach cyklu „Lesby, na które trzeba uważać” pojawia się także Bruce Bechdel: chociaż Mo została obdarzona konwencjonalnymi rodzicami, autorka dokonała ich proustowskiej transpozycji w inne postacie. Sydney, dziewczyna Mo, ma matkę Helen (jak Alison z Fun Home, i jak sama Bechdel). Ojciec Sydney, Paul Krukofsky, jest wcieleniem Bruce'a, nauczyciela literatury mającego romanse z uczniami (z tym że Paul jest profesorem uniwersyteckim i jego romanse są heteroseksualne).

Po drugie, w 1993 roku Bechdel opublikowała ur-tekst dla Fun Home - Coming Out Story (Historię coming outu) - w którym literalnie ujawnia swoją seksualność bezpretensjonalnym: „Jestem lesbijką”20. Po trzecie, co unikatowe dla komiksu lesbijskiego, w graficznej warstwie Fun Home Bechdel bywa dosadna jak pornografka, choć jednocześnie jest to erotyzm „zmediatyzowany” (masturbacja podczas lektury, 84; cunnilungus podczas lektury, 89, 222) ${ }^{21}$.

Ta sama wyzwolona Bechdel przedstawia w Fun Home - co stanowi jeszcze jeden przejaw dialektyki ujawnienia i ukrycia - obraz

${ }_{17}$ Tamże, s. 15 .

${ }^{18}$ Tamże, s. 20.

${ }^{19}$ Zob. A. Bechdel, The Essential Dykes to Watch Out For, London 2009.

${ }^{20}$ A. Bechdel, Coming Out Story, http://www.oberlinlgbt.org/bechdel/bechdel-1.html [dostęp 20.02.2016].

${ }^{21}$ Zob. A.F. Wysocki, Drawn Together. Possibilities for Bodies in Words and Pictures, [w:] Composing (Media) = Composing (Embodiment): Bodies, Technologies, Writing, the Teaching of Writing, ed. K.L. Arola, A.F. Wysocki, Logan (UT) 2014, s. 40. 
homoseksualności jako patologii. Po pierwsze, buduje go Bruce, ujmujący własne skłonności w kategoriach choroby i przekonania o konieczności terapii. Po drugie, tworzą go obszerne passusy Alison na temat jej zaburzeń obsesyjno-kompulsywnych i Freudowskiego idiomu odwrócenia (czytelne jako nieuświadomione mechanizmy obronne ego). Po trzecie, Bechdel ustami swoich postaci wyraża ubolewanie, że kultura lesbijska przeniknęła kulturę popularną i tęskni za subkulturą mniejszości.

Ale najmocniejszym sposobem, w jaki Bechdel aktualizuje w Fun Home dialektykę ukrycia i ujawnienia, są równie częste, co jawne aluzje intertekstualne. Bechdel tytułuje każdy z rozdziałów cytatem z innego tekstu: np. rozdział pierwszy nosi tytuł „Praojcze, artysto sprzed wieków” (9). Ponadto rysuje na planszach Fun Home inne dzieła literackie (i nie tylko, jak w wypadku „Esquire”) jako wizualne klucze interpretacyjne. Te aluzje jednocześnie ujawniają/wyostrzają konfesyjny ton utworu (dramatyczna natura codziennego życia) oraz ukrywają: prowadzą narrację, która separuje od dramatu rodziny Bechdel.

Już na pierwszej planszy Fun Home Bechdel przekształca dziecięcą zabawę w samolot $\mathrm{w}$ wielowarstwowe odniesienie do mitu ikaryjskiego (ojciec i dziecko, wzlot Alison, upadek Bruce’a, „Dedal wystroju” itd.), jednocześnie umieszczając obok ojca widoczny tom Anny Kareniny. Obie aluzje - w jednym kadrze - odsyłają do samobójstwa Bruce’a.

W metafikcjonalnym ruchu powracają one w ostatniej planszy (240) narracji. W niej Tołstojowski pociąg - obecny jako obraz w filmie, który Alison ogląda z ojcem podczas ich przedostatniego spotkania (230) - staje się ciężarówką Sunbeam Bread ${ }^{22}$, pod którą w domyśle leży Bruce. Leży w takiej samej pozycji, w jakiej przytrzymuje Alison „robiącą” samolot (11) i w takim samym, w jakim łapie ją, skaczącą do basenu (240). Ten ostatni kadr komiksu jest zresztą iteracją (prze-pisaniem) archiwalnej fotografii rodzinnej, już przerysowanej (prze-pisanej) przez Bechdel w planszy

${ }^{22}$ Ciężarówka Sunbeam Bread pojawia się, niespodziewanie, jak fatalistyczny znak ironii losu w opowieści Alison Bechdel o przyznaniu się matce, że od roku pracuje nad komiksem poświęconym nieżyjącemu ojcu: „Zdecydowałam się powiedzieć jej osobiście, kiedy pojadę z wizytą na święta. Byłam niespokojna, jak poruszyć ten temat; dziewięć godzin drogi do jej domu ćwiczyłam, co chciałabym powiedzieć. Kiedy dojeżdżałam do Scranton, niedaleko celu, miałam gotowe kwestie. Ruch na tym odcinku zawsze jest duży; raptem ciężarówka wepchnęła się na pas tuż przede mną - byłam najprawdopodobniej w jej martwym polu. Musiałam zjechać na pobocze, żeby mnie nie potrąciła. Wkurzyłam się. Gdy przyszłam do siebie, przyspieszyłam, żeby złapać numer rejestracyjny. Wtedy zobaczyłam logotyp na jej boku: była to ciężarówka Stroehmann’s Sunbeam Bread. Mój ociec zmarł, potrącony przez - a prawdopodobnie celowo skoczył pod - ciężarówkę Stroehmann's Sunbeam Bread". A. Bechdel, What the Little Old Ladies Feel: How I Told My Mother about My Memoir, [w:] Family Trouble: Memoirists on the Hazards and Rewards of Revealing Family, ed. J. Castro, Lincoln (NE) 2013, s. 71 (tłum. cytatu - L.K.). 
tytułowej ostatniego rozdziału „Podróż antybohatera” (195), a zarazem finalną iteracją powracającej rekursywnie w tekście aluzji do greckiego mitu i do Ulissesa Jamesa Joyce'a (na kurs o nim uczęszcza studentka Alison w tymże rozdziale siódmym, równolegle przeżywając lesbijską odyseję z autobiografią Sidonie-Gabrielle Colette).

Ta erupcja literackich aluzji jest właściwa dla życia Bechdel/Alison. Oboje jej rodzice to nauczyciele angielskiego. Bibliografia Fun Home obejmuje zatem nie tylko klasyczki feminizmu, ale także: a) wspomnianego Ulissesa Jamesa Joyce'a z relacją Stefana Telemacha Dedalusa i Leopolda Odyseusza Blooma, w której odbija się relacja Alison i Bruce'a'; b) Alberta Camusa, między innymi Śmierć szczęśliwa czytaną przez Bruce'a; c) Wielkiego Gatsby'ego Francisa Scotta Fitzgeralda (z oczywistą aluzją autobiograficzną do głównego bohatera i tego, że Bruce, umierając, ma czterdzieści cztery lata, jak Fitzgerald); d) W poszukiwaniu straconego czasu Marcela Prousta, które stanowi lekturę Bruce’a pozwalającą Alison-narratorce widzieć w Royu pierwowzór Albertyny Simonet - Alfreda, asystenta i szofera Prousta (102), i podjąć grę crossgenderową, gdy jako dziewięciolatka prosi brata, by zwracał się do niej Albert, zamiast Alison [121]; e) sztukę Oscara Wilde’a, między innymi Bądźmy poważni na serio, w której gra matka Alison, Helen... A jest to lista tyleż imponująca, ileż niepełna: strony Fun Home wypełnione są przerysowanymi (prze-pisanymi) gazetami, magazynami, okładkami książek, graffiti, stronami powieści, słowników, policyjnych raportów, paszportów, podręczników, kalendarzy, map, notatek, literami wykutymi na pomnikach, wystukanymi na maszynie i napisanymi ręcznie.

Sama Bechdel opisuje swój coming out jako proces czytania. Robi to już w Coming Out Story, opublikowanym na dziesięć lat przed Fun Home, w którym to utworze czytanie dystansuje od traumatycznych detali życia, a Alison przegląda książki, by odnaleźć prawdę o własnej seksualności. I to jest znów sedno dialektyki ukrycia i ujawnienia. Z jednej strony Bechdel w Coming Out Story prezentuje literaturę, książki i czytanie jako środek przeciw erotycznej prawdzie. Z drugiej strony konstruuje o niej następującą wykwintną aliterację: „a truth that was slowly but surely struggling to the surface of sex-starved soul" [prawda, która powoli walczy, by wyłonić się na powierzchni duszy spragnionej seksu ${ }^{23}$. Dystansacyjny chwyt literacki okazuje się zmysłowy sam w sobie.

Alison, zarówno w Coming Out Story, jak i w Fun Home sięga między innymi po Word Is Out, publikację wydaną w 1978 roku, zawierającą zwierzenia dwudziestu sześciu gejów i lesbijek - transkrybowane (prze-pisane) z filmu dokumentalnego Word Is Out: Stories of Some of Our

${ }^{23}$ Zob. przyp. 20. 
Lives w kolektywnej reżyserii Mariposa Film Group z 1977 roku (82-83, 211). To pierwsza z serii formacyjnych lektur dla Alison: „To, że jestem lesbijką, odkryłam w wieku dziewiętnastu lat. Było to przeżycie iście intelektualne. Objawienie nie dla ciała, a dla umysłu" (82). Na kolejnych planszach książki okazują się znów przeszkodą i pomocą w samorealizacji oraz seksualnym przebudzeniu. Alison wiąże się z Joan, radykalną poetką i „matriarchistką” o jednym sztucznym oku (co pozwala Alison kojarzyć Joan z Polifemem); wiąże się emocjonalnie i literalnie w łóżku „zawalonym książkami”, co nazywa „swoistym połączeniem teorii i praktyki" (88). Petting odbywa się tu obok tomu Adrienne Rich Dream of a Common Language, indeks wyrazów indoeuropejskich - „Oral, otwór, orgazm, odbyt” (88) współgra z penetracją językiem konchy ucha, a bajka Roala Dahla Jakubek i brzoskwinia olbrzymka zmienia się w ludyczny canilingus: „[...] ściany były wilgotne i lepkie, a z sufitu kapał brzoskwiniowy sok" (89). To jest prze-pisywanie literatury.

Sam Fun Home też okazał się bazą dla prze-pisywania. Nie tylko obrósł literaturą krytyczną i naukową, ale i stał się kanwą musicalu Jeanine Tesori (muzyka) i Lisy Kron (libretto) o tym samym tytule, granego i nagradzanego w The Public Theater na Off-Broadway w Nowym Yorku od września 2013 roku. Autorka Fun Home z powodu niefortunnego zbiegu okoliczności nie uczestniczyła w premierze musicalu (podobnie jak w pracach nad nim). Ostatecznie jego recenzję przekazała w zwykły sobie sposób: komiksem, co komplikuje relacje instancji nadawczych. Realna Alison Bechdel (dalej Bechdel) stanowi pierwowzór dla tekstualnej Alison Bechdel (dalej Alison), narratorki Fun Home, a zarazem jego bohaterki, która stanowi pierwowzór dla trzech Alison granych przez trzy aktorki w różnym wieku z musicalu Fun Home. Z ich gry realna Bechdel zdaje sprawę komiksem jako Alison oglądająca musical o sobie samej... ${ }^{24}$

Tymczasem jak gdyby nieświadoma komplikacji Bechdel prostodusznie stwierdza w rozmowie z kanałem YouTube StuckInVermont, że musical to prawdziwa historia o prawdziwych ludziach: „Nie byłoby opowieści, gdyby mój ojciec nie umarł. [...] To nie jest coś, co można świętować czy być z tego dumną". A jednocześnie na pytanie o możliwą recepcję sztuki przez nieżyjących rodziców odpowiada: „Byłoby zachwycająco, gdyby mój ojciec zobaczył swoje tapety w scenografii na Broadwayowskiej scenie. Byłby w niebie" 25 .

Moim zdaniem istnieją zatem dwie możliwości. Albo Bechdel, pisząc Fun Home. Tragikomiks rodzinny - opowieść memuarystyczną,

${ }^{24}$ A. Bechdel, Fun Home! The Musical!, http://www.sevendaysvt.com/vermont/fun-home-the-musical/Content?oid=2393463 [dostęp 20.02.2016].

${ }^{25}$ Zob. przyp. 7. 
autograficzną i sylwiczną zarazem, poświęconą domniemanemu samobójstwu jej ojca, homoseksualisty ukrywającego tożsamość seksualną; opowieść, której ikoniczno-werbalna narracja nie reprodukuje linearnej chronologii wydarzeń, lecz układa się w skomplikowany, rekursywny ciąg retrospekcji i autokomentarzy, łączących prze-pisywanie tego, co realne (archiwum rodzinnych fotografii i wspomnień), z prze-pisywaniem tego, co fikcyjne (figur mitologicznych, kanonu beletrystyki i nauk humanistycznych); opowieść opowiadaną przez sylleptyczną figurę Alison - całkowicie nie zdaje sobie sprawy z jakichkolwiek komplikacji, albo wręcz przeciwnie: mnoży całkowicie mylne tropy prostodusznej autobiografii.

Albo - i to jest trzecia, chyba najbardziej prawdopodobna możliwość - Bechdel świadomie queeruje proste binarne teorie swą metadyskursywną praktyką, epistemologiczną niepewnością i sceptycyzmem w stosunku do jakichkolwiek esencjalnych kategorii. Stąd komplikacja nawet homonormatywnej narracji w krypto-bio-grafii prze-pisującej na równi rodzinne archiwum prywatne, jak i kulturowe archiwum publiczne poprzez komiksowe medium, które samo w sobie podważa dychotomiczno-hierarchiczną relację słów i obrazów, męskiego i żeńskiego, wysokiego i niskiego ${ }^{26}$. Tym samym przeciwstawiając się fałszywemu, a dobremu samopoczuciu, że lesbijski radykalizm został oswojony przez światopoglądową hegemonię białej klasy średniej ${ }^{27}$.

\section{A dyke with dry eyes. Alison Bechdel's Fun Home as crypto-bio-graphy}

\section{Summary}

This paper is a close-reading of Alison Bechdel's comics Fun Home, subtitled A Family Tragicomic, as a complicated game with the biography of a lesbian cartoonist faking an intimate testimony of her own coming-out and her father's supposed suicide. This article analyses a dialectic relation of revealing and concealing within the book, tracking both textual and iconic strategies, accompanying Bechdel's comments and comic spin-offs as well. The main thesis is that the analysed strategy applied to the convention of queer narratives by the author is a deliberate attempt at challenging the hierarchical relations of word and image, male and female, and high and low.

${ }^{26}$ Zob. Composing (Media)..., s. 42.

${ }^{27}$ Zob. T. Thompson, Queer Attachments: Alison Bechdel and the Shifting Relationship between Queer Selves and Heteronormativity, „Women's Studies Journal” 2014, vol. 28 , no. 1 , s. $83-87$. 